\title{
Quality characteristics of whey Makgeolli by Kluyveromyces marxianus
}

\author{
Su-Hwan Kim ${ }^{1}$, Chang-Ki Huh ${ }^{2}$, So-Mang Kim ${ }^{1}$, In-Kyung Cho ${ }^{3}$, Yong-Doo Kim ${ }^{1 *}$ \\ ${ }^{1}$ Department of Food Science and Technology, Sunchon National University, Sunchon 57922, Korea \\ ${ }^{2}$ Imsil Institute of Cheese Science, Imsil 55918, Korea \\ ${ }^{3}$ Department of Food and Nutrition, Nambu University, Gwangju 62271, Korea
}

\section{Kluyveromyces marxianus에 의한 유청막걸리 품질특성}

\author{
김수환 ${ }^{1} \cdot$ 허창기 $^{2} \cdot$ 김소망 $^{1} \cdot$ 조인경 ${ }^{3} \cdot$ 김용두 $^{1 *}$ \\ ${ }^{1}$ 순천대학교 식품공학과, ${ }^{2}$ (재)임실치즈과학연구소, ${ }^{3}$ 남부대학교 식품영양학과
}

\begin{abstract}
This study was performed to analyze the processing and quality characteristics of whey Makgeolli prepared with different types of yeast and ratio of the whey content. Lactose content of yeast culture medium containing $S$. cerevisiae. was $1.36 \%$ whereas lactose content of yeast culture containing $K$. marxianus KCCM 12015 was very little. Yeast culture of both $K$. marxianus KCCM 35455 and $K$. marxianus KCCM 50700 did not produce lactose. Until the 10th day, ethanol production ability of $S$. cerevisiae, $K$. marxianus KCCM 12015, K. marxianus KCCM 35455, and $K$. marxianus KCCM were $0.31 \%, 2.51 \%, 2.53 \%$, and $2.59 \%$, respectively. Total acids content increased rapidly with the increase in the addition of whey content in the initial 2 days and then decreased during $4 \sim 10$ days of fermentation. In the aspect of $\mathrm{pH}$, the $\mathrm{pH}$ was rapidly decreased in the initial 2 days and then increased until 10th day of fermentation with the increase in whey content. Ethanol content of whey Makgeollis at 10th day of fermentation was the highest in yeast culture containing $K$. marxianus. From the sensory evaluation, the flavor score of whey Makgeollisin was higher than that of control. The color and taste scores were increased as the increase in the addition of whey. The comprehensive preference indicated that Makgeolli prepared with $100 \%$ whey was the best among other samples.
\end{abstract}

Key words : Makgeolli, Kluyveromyces marxianus, whey, fermentation, lactose

\section{서 론}

유청이란 치즈제조 과정의 부산물을 말하며(1), 치즈가 제조되기 시작한 $\mathrm{BC} 5,000$ 년부터 생산 및 사용이 되었다 (2). 유청은 치즈 $1 \mathrm{~kg}$ 제조 시 치즈 생산량의 10 배인 10 $\mathrm{kg}$ 정도로 $1: 10$ 의 비율로 생산된다고 보고되어 있다(3). 이렇게 생산된 유청은 수용성 단백질, 유당, 미네랄, 비타민, 아미노산, 젖산 및 효소 등이 포함되어 있고 우수한 유화작 용, 거품생성 기포형성, 젤라틴화 및 용해성 등 여러 기능적

*Corresponding author. E-mail : kyd4218@sunchon.ac.kr Phone : 82-61-750-3256, Fax : 82-61-750-3208

Received 9 March 2015; Revised 25 June 2015; Accepted 24 July 2015.

Copyright (c) The Korean Society of Food Preservation. All rights reserved.
인 특성으로 인하여 과거에는 폐기 처분되었던 물질이 최근 에는 새로운 식품재료와 식품첨가물로써 이용가치가 높게 평가되고 있으나 $(4,5)$, 국내에서는 양이 적고 이용할 수 있 는 기반 시설이 미비하여 BOD가 $35 \sim 45 \mathrm{~kg} / \mathrm{L}$ 가 요구되는 유청을 정화 처리하여 폐기하는 실정이다(6).

유청은 과거에 주로 액체 상태로 동물에게 사료로 급여 하였으며, 중세시대에는 약제, 정력제, 피부 방향제로써 이 용하였다. 또한, 화상을 완화시키거나 체력을 회복시키고 질병을 치료하는 약제나 연고의 구성성분으로서도 이용한 것으로 나타났다(7).

현재 인류의 식품이나 동물사료로 이용되고 있는 유청은 여러 가지 형태로 제조, 분리, 배합되어(8) 기능성 식품소재, 의약품 소재, 필름과 코팅제, 유청 함유물, 화장품 및 생필품 등 그 형태와 종류는 수없이 많다(5).

유청을 이용한 알코올 발효적성 및 음료의 개발연구는 
국외의 경우, Zafar과 Owais(9)는 Kluyveromyces marxianus 균주를 이용해 알코올 발효적성에 대한 연구를 보고한 바 있으며, Dragone 등(10)은 유청을 발효시켜 제조된 알코올 음료의 휘발성 화합물의 특성에 관한 내용을 보고 하였다 $(11,12)$. 국내에서는 Shim 등(13)과 $\mathrm{Kim}$ 등(14)은 $K$ marxianus와 lactic acid bacteria균주를 이용한 유청 알코올 발효적성에 관한 연구와 유청을 탁주 용수로 이용하기 위한 발효 적성에 관한 연구 보고가 이루어진바 있다.

막걸리는 우리나라의 전통발효주의 하나로 막 거른 술이 라는 의미로부터 유래되어 맑지 않고 탁하기 때문에 “탁주” 라고 부르기도 하고, 농부들이 갈증이나 배고픔을 해소하 기 위하여 새참으로 즐겨 음용하였다고 하여 “농주”라고도 불리어져 왔다(15). 국내 막걸리에 관한 연구는 대부분이 전분질 원료 및 누룩(입국)에 관한 연구 $(16,17)$ 와 부재료 첨가에 따른 품질특성 $(18,19)$ 에 관한 연구가 진행 되었고, 최근 막걸리의 담금 용수에 관한 연구로 Lee(20)의 자작나 무 수액을 활용한 탁주 제조와 Son 등(21)의 가수량을 달리 한 탁주 제조 연구 등이 이루어지면서 담금 용수에 대한 관심이 높게 나타나고 있다.

따라서 본 연구는 국내에서 대부분 폐기 되는 유청을 막걸리 담금 용수로 활용하기 위하여 유청의 알코올 발효에 적합한 효모를 선정하고, 유청과 물의 첨가 비율을 달리한 유청 막걸리의 품질특성을 확인하여 유청 활용 및 전통주인 막걸리 발전을 도모하고자 하였다.

\section{재료 및 방법}

\section{재료 및 사용균주}

실험에 사용된 유청은 2014년 4월 전라북도 (재)임실치 즈과학연구소에서 제 공받아 $62^{\circ} \mathrm{C}$ 에서 30 분간 저온 살균하 여 냉각시킨 후 $4^{\circ} \mathrm{C}$ 에서 냉장 및 $-50^{\circ} \mathrm{C}$ 에서 냉동보관 하면서 사용하였고, 쌀은 2013년 전남농업기술원에서 한아름 품종 을 제공 받아 사용하였다. 입국은 시판백국인 조제종국(주) 충무발효, Ulsan, Korea)을 구입하여 입국 제조에 사용하였 다. 막걸리 제조용 효모는 시판 건조효모인 Saccharomyces cerevisiae(Laparisienne, S. I. Lesaffre, France)를 구입하여 사용하였으며, K. marxianus KCCM 12015, K marxianus KCCM 35455 및 K. marxianus KCCM 50700 3종을 한국미 생물보존센터에서 분양받아 사용하였다.

\section{유청의 효모별 배양 조건}

배양액은 $62^{\circ} \mathrm{C}$ 에서 30 분간 저온 살균하여 냉각시킨 유청 $500 \mathrm{~mL}$ 에 $K$ marxianus 3종을 각각 $5 \mathrm{~mL}$ 씩 접종하여 $28^{\circ} \mathrm{C}$ 에서 10 일 동안 배양하였으며, 시판효모인 S. cerevisiae를 대조구로 하여 동일한 조건으로 배양하였다.

\section{유청 발효액의 유당 함량 측정}

유당 성분의 분석은 Wilson(22)의 방법에 따라 시료를 전처리하여 HPLC(Waters M510, Waters Co., Milford, MA, USA)로 분석하였다. Column은 Carbohydrate column(ID $4.6 \times 50 \mathrm{~mm}$, Grace Co., Deerfield, IL, USA)를 사용하였으며, mobile phase는 $75 \%$ acetonitrile, flow rate는 $1.0 \mathrm{~mL} / \mathrm{min}$, detector는 ELSD(2000ES, Alltech Co., Vienna, VA, USA)를 사용하였다. 함량은 외부표준법으로 계산하였다.

\section{유청 발효액의 에탄올 함량 측정}

Ethanol 함량은 시료를 여과하여 여액 $1 \mu \mathrm{L}$ 를 $\mathrm{GC}$ 에 주입 하였으며 외부 표준법으로 계산하였다. $\mathrm{GC}$ 분석조건은 Carbopack B/PEG 20M 5\%(ID $3 \mathrm{~mL} \times 4$ mm, Hewlett Packard Co., Palo Alto, CA, USA)를 사용하여 오븐온도는 $60^{\circ} \mathrm{C}$ 에서 $150^{\circ} \mathrm{C}$ 까지 $5^{\circ} \mathrm{C} / \mathrm{min}$ 속도로 상승시켰고 주입기와 검출기의 온도는 각각 $220^{\circ} \mathrm{C}$ 와 $250^{\circ} \mathrm{C}$, carrier gas는 $\mathrm{N}_{2}$ 를 사용하였다.

\section{입국제조}

본 실험에 사용된 입국은 쌀 $1 \mathrm{~kg}$ 을 5 시간 동안 물에 침지시킨 후 30 분간 증자하여 $30^{\circ} \mathrm{C}$ 로 냉각시킨 다음, 시판 백국을 접종하고 $30^{\circ} \mathrm{C}$ 에서 3 일간 배양하여 양조용 입국으 로 사용하였다.

\section{주모제조}

주모제조는 입국 $500 \mathrm{~g}$ 에 물 $750 \mathrm{~mL}$ 를 첨가하여 젖산 $0.5 \%$ 를 혼합하고 시판효모인 $S$. cerevisiae와 $K$ marxianus 3 종을 $50 \mathrm{~mL}$ 씩 각각 첨가하여 $25^{\circ} \mathrm{C}$ 에서 6 일간 발효시켰다.

\section{유청 첨가비율에 따른 막걸리 제조}

1 단 담금은 쌀 $2 \mathrm{~kg}$ 에 담금용수로 $62^{\circ} \mathrm{C}$ 에서 30 분간 저온 살균하여 냉각시킨 유청 $50 \%$ (물 $1.5 \mathrm{~L}$ : 유청 $1.5 \mathrm{~L}$ ) 및 $100 \%$ (유청 $3 \mathrm{~L}$ )로 각각 첨가한 후 정제효소((주) 바이오랜 드, Ansan, Korea)를 0.3\%씩 혼합하고, 전 배양한 주모를 $1 \mathrm{~L}$ 씩 첨가하여 $25^{\circ} \mathrm{C}$ 에서 3 일간 발효 시켰다. 대조구로는 유청 대신 물 $3 \mathrm{~L}$, 정제효소 $0.3 \%$ 와 주모 $1 \mathrm{~L}$ 를 첨가한 후 동일한 조건 하에서 발효시켰다. 2 단 담금은 1 단 담금된 술덧에 쌀 $4 \mathrm{~kg}$ 에 담금용수로 $62^{\circ} \mathrm{C}$ 에서 30 분간 저온 살균하 여 냉각시킨 유청 $50 \%$ (물 $2.5 \mathrm{~L}$ : 유청 $2.5 \mathrm{~L}$ ) 및 $100 \%$ (유청 $5 \mathrm{~L}$ )로 각각 첨가한 후 정제효소를 $0.3 \%$ 씩 혼합하고 $25^{\circ} \mathrm{C}$ 에 서 10 일간 발효시켰다. 대조구로는 유청 대신 물 $5 \mathrm{~L}$ 와 정제효소 $0.3 \%$ 를 첨가하여 동일한 조건 하에서 발효시켜 A 시료구 $(S$ cerevisiae + water $100 \%)$, B 시료구 $(S$. cerevisiae + water $50 \%$, whey $50 \%), \mathrm{C}$ 시료구 $(S$ cerevisiae + whey $100 \%)$, D 시료구(K. marxianus KCCM 50700+water100\%), $\mathrm{E}$ 시료구(K. marxianus $\mathrm{KCCM} 50700+$ water 50\%, whey $50 \%$ ) 및 $\mathrm{F}$ 시료구(K marxianus $\mathrm{KCCM} \mathrm{50700+whey} \mathrm{100 \% )}$ 를 제조하여 품질특성과 관능평가를 실시하였다. 


\section{총산과 $\mathrm{pH}$ 측정}

총산 함량은 시료를 원심분리하여 상등액 $10 \mathrm{~mL}$ 를 취해 $0.1 \mathrm{~N} \mathrm{NaOH}$ 용액으로 적정한 후 0.009 를 곱하여 lactic acid 로 환산하였다. $\mathrm{pH}$ 는 시료 $20 \mathrm{~mL}$ 를 취하여 $\mathrm{pH}$ meter를 사용하여 측정하였다.

\section{환원당 함량 측정}

환원당 함량 변화는 Somogyi 변법(23)에 준하여 측정하 였다. 즉, 시료 $10 \mathrm{~mL}$ 를 Somogyi 변법에 의해 정량하여 glucose 함량으로 표시하였다.

\section{Ethanol 함량 측정}

Ethanol 함량은 시료를 여과하여 여액 $1 \mu \mathrm{L}$ 를 $\mathrm{GC}$ 에 주입 하였으며 분석조건은 유청 발효액의 에탄올 함량 측정 방법 과 같다.

\section{관능평가}

유청 첨가비율에 따른 막걸리의 관능검사는 panel 10 명 을 대상으로 하여 향(flavor), 색(color), 맛(taste)을 평가항목 으로 하고 최종적으로 전체적인 기호도(overall preference) 를 9단계 평가법(24)으로 실시하였다. 채점 기준은 아주 좋다; 9점, 보통이다; 5 점, 아주 나쁘다; 1 점으로 하였다. 2 시간 간격으로 시료의 번호를 바꾸어 같은 panel들로 3 회 반복하였으며, 각 반복 시 가장 높은 점수와 가장 낮은 점수 를 제외하고 평균 득점을 구하였다. 관능평가 결과는 Duncan's multiple range test(25)에 의해 평균치간의 유의성 을 검정하였다.

\section{통계처리 방법}

본 실험은 독립적으로 3 회 이상 반복 실시하여 실험결과 를 IBM SPSS statistics(21, IBM Corp., Armonk, NY, USA) 통계분석 프로그램을 이용하여 각 실험군간 평균치와 표준 편차를 계산하였다.

\section{결과 및 고찰}

\section{유청 발효액의 유당과 ethanol 함량}

배양기간에 따른 효모 배양액의 유당 함량을 측정한 결 과는 Fig. 1 과 같다. 초기 유당함량 $3.53 \%$ 인 배양액에서 대조구 균주인 $S$. cerevisiae 는 2 10 일 까지 $2.17 \%$ 의 함량이 감소되어 10 일째 $1.36 \%$ 의 유당이 존재하였지만 $K$. marxianus KCCM 12015, K marxianus KCCM 35455 및 K. marxianus KCCM 50700의 효모 배양액에서 유당함량이 각각 $3.52 \%, 3.53 \%$ 및 $3.53 \%$ 가 급격하게 감소되어 $K$. marxianus KCCM 12015의 균주에서만 유당이 미량 검출되 었다. Zafar와 Owais(9)는 유당 $3.5 \%$ 의 배지에서 $K$. marxianus균주를 이용하여 발효특성을 관찰하였으며 유당 은 초기부터 급격히 감소하여 20 시간 이후 $0.5 \%$ 이하로 감 소하였다. 본 연구와의 유당 분해 시간이 차이 나는 것은 발효 조건과 질소원 추가에 따른 배지조성이 다르기 때문으 로 생각된다. ethanol을 측정한 결과는 Fig. 2 와 같다. 유당함 량 $3.53 \%$ 의 배양액에서 10 일간 ethanol 생성능을 비교하였 다. 대조구인 $S$. cerevisiae는 최고 $0.31 \%$ 의 ethanol을 생산한 것에 비하여 $K$. marxianus KCCM 12015, K marxianus KCCM 35455 및 $K$ marxianus KCCM 50700 3종 모두 2일 이후 급격히 ethanol 함량이 상승하였으며, 10 일째 각각 $2.51 \%, 2.53 \%$ 및 $2.59 \%$ 의 ethanol 함량을 보여 $K$ marxianus $\mathrm{KCCM} 50700$ 균주의 ethanol 함량이 가장 높은 것으로 나타 났다. 본 연구 결과 이론적 수득률(theoretical yield) 보다 높은 함량을 보였으나, Galanakis 등(26)은 유청에서 유당

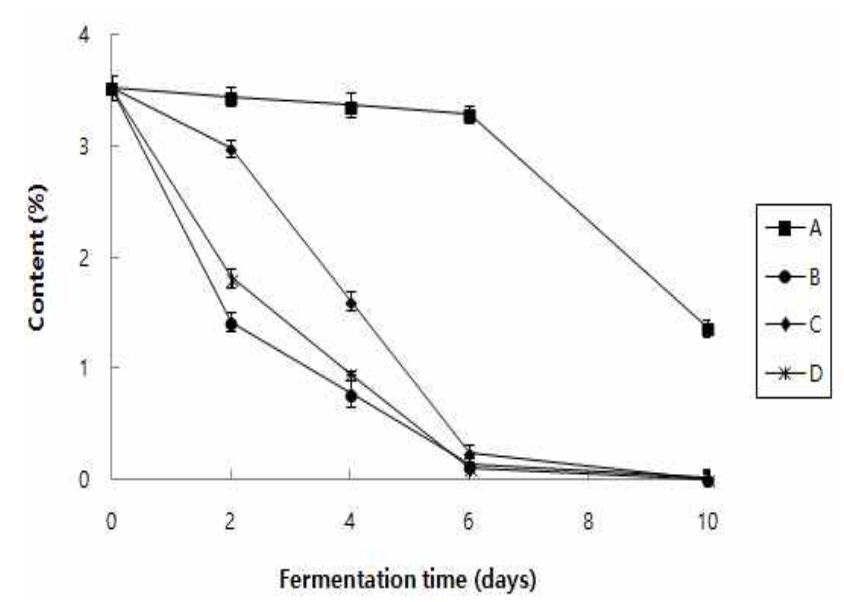

Fig. 1. Changes in lactose contents of whey during fermentation with various yeast strains.

A, Saccharomyces cerevisiae, B, Kluyveromyces marxianus KCCM 12015; C, Kluyveromyces marxianus KCCM 35455; D, Kluyveromyces marxianus KCCM 50700.

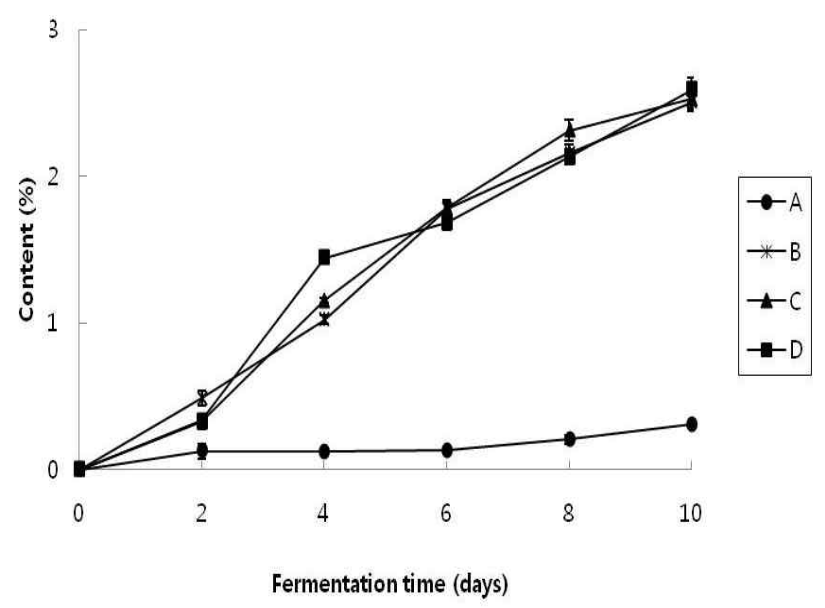

Fig. 2. Changes in ethanol contents of whey during fermentation with various yeast strains.

A, Saccharomyces cerevisiae, B, Kluyveromyces marxianus KCCM 12015; C, Kluyveromyces marxianus KCCM 35455 ; D, Kluyveromyces marxianus KCCM 50700. 
이외의 당이 존재함을 보고하여 높은 ethanol 함량을 보인 것은 유당 이외의 다른 당의 ethanol 발효에 의한 영향으로 사료된다. Shim 등(13)은 유당 $4.5 \%$ 의 배지에 각각 $2 \%$ 의 S. cerevisiae와 $K$ marxianus를 접종하여 $37^{\circ} \mathrm{C}$ 에서 배양시 켜 ethanol 변화를 보고하였으며, $S$ cerevisiae와 $K$. marxianus는 최고 함량이 각각 $0.2 \%$ 와 $2.8 \%$ 로 보고해 본 연구와 유사한 경향을 나타내었다. 따라서 유당 분해능과 ethanol 생성능이 우수했던 K. marxianus KCCM 50700의 효모를 선정하여 유청 막걸리 제조 연구를 진행하였다.

\section{유청 첨가비율에 따른 막걸리의 품질 특성 총산과 $\mathrm{pH}$}

유청 첨가비율에 따른 막걸리의 발효과정 중 총산의 변 화는 Fig. 3과 같다. 담금 직후 산도는 $0.21 ~ 0.75 \%$ 였고, 담금 2 일에 산도가 $1.35 ~ 2.68 \%$ 로 급격하게 증가하였다가 발효 4일에는 0.50 0.72\%로 감소하였다. 그 후 모든 시료구 가 완만히 감소하여 10 일째에는 $\mathrm{A}$ 시료구 $0.15 \%, \mathrm{~B}$ 시료구 $0.21 \%, \mathrm{C}$ 시료구 $0.24 \%, \mathrm{D}$ 시료구 $0.17 \%, \mathrm{E}$ 시료구 $0.16 \%$, $\mathrm{F}$ 시료구 $0.21 \%$ 로 나타났으며, K. marxianus KCCM 50700 으로 담금한 시료구의 경우 시판 효모로 담금한 막걸리의 산도보다 비교적 낮은 경향을 보였다. 본 연구의 모든 시료 구는 10 일째 총산 함량이 $0.15 ~ 0.24 \%$ 로 국립농산물품질관 리원의 술 품질인증기준(27)에서 고시한 막걸리 총산 기준 인 $0.5 \%$ 이하에 충족하는 것으로 나타났다. $\mathrm{pH}$ 변화는 담금 직후 5.26 5.67이었으며, 담금 2일에 $\mathrm{pH}$ 가 4.00 4.67로 저 하하였다. 그 후 모든 시료구가 완만히 상승하여 10 일째에 는 A 시료구 $4.90, \mathrm{~B}$ 시료구 $4.95, \mathrm{C}$ 시료구 $4.66, \mathrm{D}$ 시료구 $4.95, \mathrm{E}$ 시료구 4.94 및 $\mathrm{F}$ 시료구 4.93으로 나타났으며, $K$ marxianus $\mathrm{KCCM}$ 50700로 담금한 시료구의 경우 시판 효모

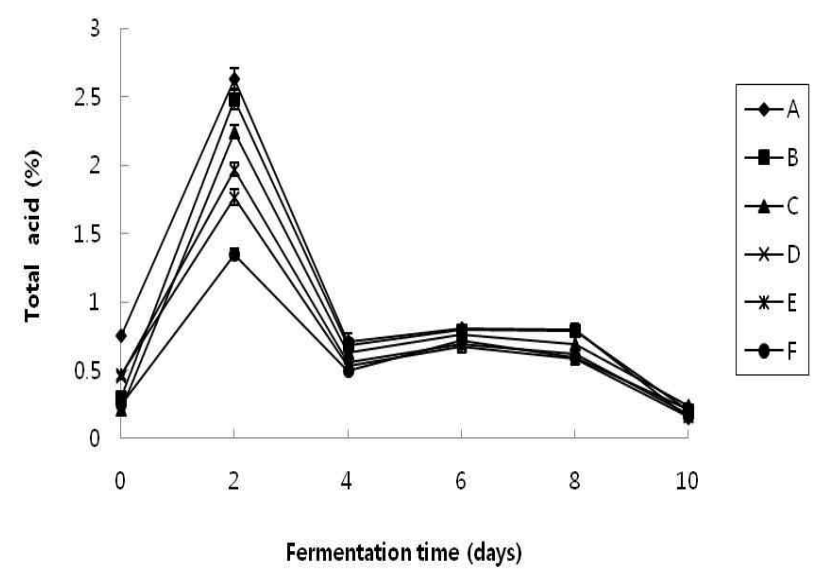

Fig. 3. Changes in total acid contents of Makgeolli according to whey addition ratio during fermentation.

A, Saccharomyces cerevisiae +(Water 100\%); B, Saccharomyces cerevisiae +(Water 50\% + Whey 50\%); C, Saccharomyces cerevisiae + (Whey 100\%); D, Kluyveromyces marxianus KCCM 50700+(Water 100\%); E, Kluyveromyces marxianus KCCM 50700+ (Water 50\% + Whey 50\%); F, Kluyveromyces marxianus KCCM 50700+(Whey 100\%).
인 S. cerevisiae로 담금한 막걸리의 $\mathrm{pH}$ 보다 비교적 높은경 향을 보였다. 이러한 경향은 Kwon(28)과 Kim 등(29)과의 보고와 유사하였으며, Park 등(30)은 막걸리 제조 시 효모 외의 다른 세균을 억제하기 위해 $\mathrm{pH} 4.0$ 6.0을 유지 하는 것이 적합 하다는 보고를 하여 본 연구의 모든 시료구가 막걸리 제조 시 적합한 $\mathrm{pH}$ 를 유지하는 것으로 나타났다 (data not shown).

\section{환원당}

유청 첨가비율에 따른 막걸리의 발효과정 중 환원당 함 량 변화는 Fig. 4와 같다. 담금 직후 환원당 함량은 3.14 6.54\%이며, 발효 2일째 유청을 첨가하지 않은 $\mathrm{A}$ 시료 구와 $\mathrm{D}$ 시료구가 급격히 증가하여 최고 함량을 보였고, 발효 4일째 까지 급격히 감소하는 경향을 보였다. 발효 10 일 째 환원당 함량은 $\mathrm{A}$ 시료구 $1.05 \%, \mathrm{D}$ 시료구 $1.12 \%, \mathrm{~F}$ 시료구 $1.15 \%, \mathrm{E}$ 시료구 $1.23 \%, \mathrm{~B}$ 시료구 $2.34 \%$ 및 $\mathrm{C}$ 시료 구 $2.76 \%$ 순으로 높게 나타났다. 전체적으로 $S$ cerevisiae의 시료구에서는 유청 첨가비율이 높아짐에 따라 환원당 함량 이 높아졌으며, K. marxianus KCCM 50700 시료구에서는 큰 함량 차이가 나타내지 않았다. 이는 유당 분해효모인 K. marxianus KCCM 50700 에 비해 S. cerevisiae의 유당 분해능이 떨어져 나타난 결과로 생각되며, 균주에 따라 다 른 경향을 나타내었다. Lee 등(31)은 전분질 원료를 달리하 여 담금한 탁주의 환원당 함량을 연구 보고 하였으며 본 연구와 유사한 경향을 나타내어 균주 특성별 유청 첨가 비율에 따른 변화가 나타남을 확인하였다.

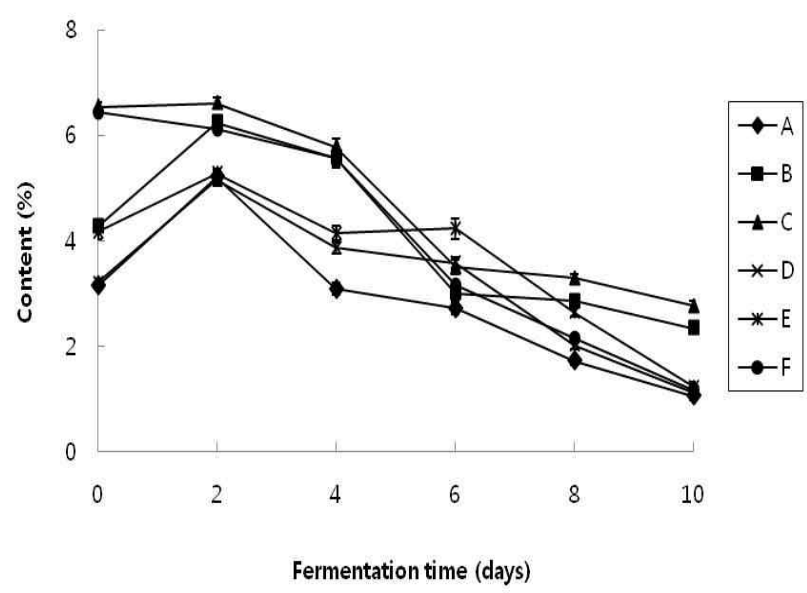

Fig. 4. Changes in reducing sugar contents of Makgeolli according to whey addition ratio during fermentation.

A, Saccharomyces cerevisiae +(Water 100\%); B, Saccharomyces cerevisiae +(Water $50 \%$ + Whey 50\%); C, Saccharomyces cerevisiae +(Whey 100\%); D, Kluyveromyces marxianus KCCM 50700+(Water 100\%); E, Kluyveronyces marxianus KCCM 50700+ (Water 50\% + Whey 50\%); F, Kluyveromyces marxianus KCCM 50700+(Whey 100\%).

\section{Ethanol}

유청 첨가비율에 따른 막걸리의 발효과정 중 ethanol 함 량 변화는 Fig. 5와 같다. 담금 직후 ethanol 함량은 
1.70 3.97\%로 나타났으며, 발효 2일째에 9.52 12.96\%로 급 격하게 증가하다가 이 후 증가폭이 둔화되었다. 이는 Lee 등(32)과 유사한 경향을 보이며 발효가 진행되었고, 발효 10 일째 알코올 함량은 $16.20 ~ 18.90 \%$ 로 각각 $\mathrm{A}$ 시료구 $16.80 \%, \mathrm{~B}$ 시료구 $17.10 \%, \mathrm{C}$ 시료구 $16.20 \%, \mathrm{D}$ 시료구 $16.80 \%, \mathrm{E}$ 시료구 $17.60 \%$ 및 $\mathrm{F}$ 시료구 $18.90 \%$ 로 나타났다. 유청 비율에 따른 ethanol 함량은 $K$. marxianus KCCM 50700로 담금한 시료구가 S. cerevisiae로 담금한 시료구 보다 높게 나타났다. S. cerevisiae의 경우 유청 $100 \%$ 를 첨가 한 막걸리의 ethanol 함량이 가장 낮게 나타났는데 이는 S. cerevisiae가 K marxianus KCCM 50700에 비해 유당 발효능이 떨어져 나타난 결과로 생각된다.

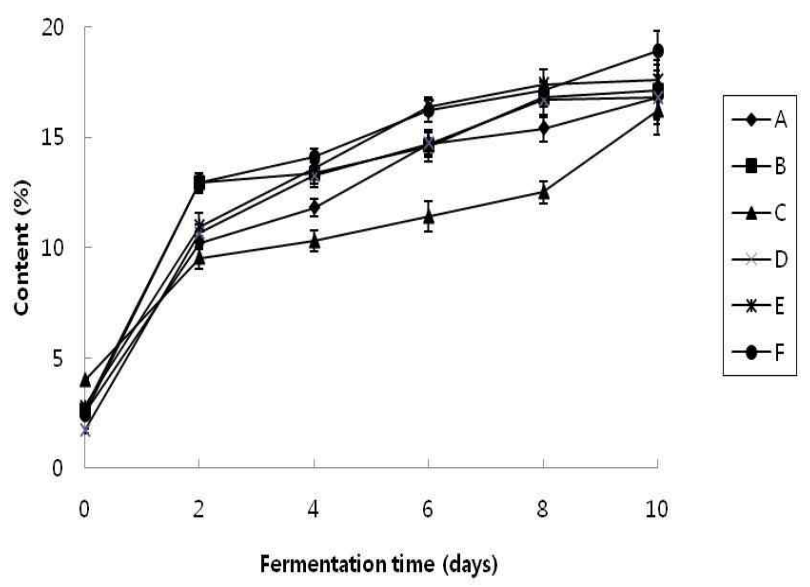

Fig. 5. Changes in ethanol contents of Makgeolli according to whey addition ratio during fermentation.

A, Saccharomyces cerevisiae + (Water 100\%); B, Saccharomyces cerevisiae + (Water $50 \%$ +Whey 50\%); C, Saccharomyces cerevisiae +(Whey 100\%); D, Kluyveromyces marxianus KCCM 50700+(Water 100\%); E, Kluyveromyces marxianus KCCM $50700+$ (Water 50\% + Whey 50\%); F, Kluyveromyces marxianus KCCM 50700+(Whey 100\%).

\section{관능평가}

유청 첨가비율에 따른 막걸리의 관능평가 결과는 Table 1 과 같다. 향의 기호도는 $S$. cerevisiae 와 $K$. marxianus $\mathrm{KCCM} 50700$ 으로 제조한 대조구인 $\mathrm{A}$ 시료구와 $\mathrm{D}$ 시료구의 기호도가 높게 나타났으며, 유청 50\%를 첨가한 B 시료구와 $\mathrm{E}$ 시료구에서 비교적 낮은 기호도를 보였다. 색과 맛의 기호도는 유청 첨가비율이 증가할수록 높은 기호도를 보였 으며, 맛의 경우 K. marxianus KCCM 50700으로 제조한 $\mathrm{F}$ 시료구가 가장 높은 기호도를 나타내었다. 종합적인 기호 도는 농도에 따라 차이를 보였다. 유청 $50 \%$ 를 첨가한 $\mathrm{B}$ 시료구와 $\mathrm{E}$ 시료구가 가장 낮은 기호도를 보였으며, 다음으 로 대조구인 $\mathrm{A}$ 시료구와 $\mathrm{D}$ 시료구 순으로 기호도를 보였다. 가장 높은 기호도를 보인 시료구는 유청 $100 \%$ 를 첨가한 $\mathrm{C}$ 시료구과 $\mathrm{F}$ 시료구로 나타났다. 따라서 향, 색, 맛 및 종합 기호도면에서 유청 $100 \%$ 첨가 시료구인 $\mathrm{F}$ 시료구가 우수한 기호도를 나타낸 것으로 보아 막걸리 제조시 담금용수로 유청 $100 \%$ 첨가가 적합할 것으로 나타났으며, 이는 막걸리
의 관능적 특성을 향상시키는데 기여할 수 있을 것으로 생각된다.

Table 1. Sensory evaluation of Makgeolli according to whey addition ratio of final products

\begin{tabular}{ccccc}
\hline & \multicolumn{4}{c}{ Sensory parameters } \\
\cline { 2 - 5 } Samples $^{1)}$ & Flavor & Color & Taste & $\begin{array}{c}\text { Overall } \\
\text { preference }\end{array}$ \\
\hline A & $6.4 \pm 0.74^{2) b 3)}$ & $5.3 \pm 0.83^{\mathrm{ab}}$ & $6.1 \pm 0.71^{\mathrm{ab}}$ & $5.6 \pm 0.74^{\mathrm{ab}}$ \\
B & $5.1 \pm 1.55^{\mathrm{a}}$ & $5.5 \pm 0.92^{\mathrm{ab}}$ & $6.4 \pm 1.07^{\mathrm{ab}}$ & $4.4 \pm 1.60^{\mathrm{a}}$ \\
C & $5.6 \pm 0.92^{\mathrm{ab}}$ & $6.0 \pm 0.76^{\mathrm{ab}}$ & $6.5 \pm 1.06^{\mathrm{ab}}$ & $6.0 \pm 0.76^{\mathrm{ab}}$ \\
D & $6.3 \pm 0.71^{\mathrm{ab}}$ & $4.8 \pm 1.04^{\mathrm{a}}$ & $5.8 \pm 1.58^{\mathrm{a}}$ & $5.9 \pm 0.64^{\mathrm{ab}}$ \\
E & $5.5 \pm 0.93^{\mathrm{ab}}$ & $5.8 \pm 0.53^{\mathrm{ab}}$ & $6.0 \pm 1.49^{\mathrm{ab}}$ & $4.8 \pm 1.39^{\mathrm{ab}}$ \\
F & $5.8 \pm 1.39^{\mathrm{ab}}$ & $6.1 \pm 0.46^{\mathrm{b}}$ & $6.8 \pm 0.83^{\mathrm{b}}$ & $6.3 \pm 0.71^{\mathrm{b}}$ \\
\hline
\end{tabular}

${ }^{1)}$ A, Saccharomyces cerevisiae + (Water 100\%); B, Saccharomyces cerevisiae + (Water 50\% + Whey 50\%); C, Saccharonyces cerevisiae +(Whey 100\%); D, Kluyveromyces marxianus KCCM 50700+(Water 100\%); E, Kluveromyces marxianus KCCM 50700 +(Water 50\% + Whey 50\%); F, Kluyveromyces marxianus KCCM 50700+(Whey $100 \%)$

${ }^{2)}$ All values are mean $\pm S D$.

${ }^{3}$ Means with different superscript letters in the same column are significantly different at $p<0.05$ by Duncan's multiple range test. $a<b$.

\section{요 약}

유청을 막걸리 제조시 용수로 사용하기 위해 효모에 따 른 유당 분해능과 ethanol 생성능력을 측정하고, 유청 첨가 비율에 따른 막걸리를 제조하여 총산, $\mathrm{pH}$, 환원당, ethanol 및 관능평가 등 품질특성을 확인한 결과는 다음과 같다. 유당 분해능은 K. marxianus KCCM 35455과 K. marxianus $\mathrm{KCCM} 50700$ 이 가장 뛰어난 유당 분해능을 보였으며, ethanol 생성능력은 K. marxianus KCCM 50700 균주의 ethanol 함량이 가장 높은 것으로 나타났다. 따라서 유당 분해능과 ethanol 생성능이 우수했던 $K$. marxianus KCCM 50700 의 효모를 선정하여 유청 막걸리 제조 연구를 진행하 였다. 유청 첨가비율에 따른 막걸리의 발효과정 중 총산은 K. marxianus KCCM 50700으로 담금한 시료구의 경우 S. cerevisiae로 담금한 막걸리의 산도보다 비교적 낮은 경향을 보였으며, $\mathrm{pH}$ 는 $K$ marxianus KCCM 50700로 담금한 시료 구의 경우 S. cerevisiae로 담금한 막걸리의 $\mathrm{pH}$ 보다 비교적 높은 경향을 보였다. 환원당 함량은 S. cerevisiae 시료구에 서는 유청 첨가비율이 높아짐에 따라 환원당 함량이 높아졌 으며, K. marxianus KCCM 50700 시료구에서는 큰 함량 차이가 나타내지 않았다. ethanol 함량 변화는 $K$ marxianus KCCM 50700로 담금한 시료구가 S. cerevisiae로 담금한 시료구 보다 높게 나타났다. 관능평가는 향, 색, 맛 및 종합 기호도면에서 K. marxianus KCCM 50700로 담금한 유청 $100 \%$ 첨가 시료구가 높은 기호도를 보였다. 


\section{감사의 글}

본 연구는 산업통상자원부 지역특화산업 융복합연구지 원사업(R0002042)의 일환으로 수행되었으며, 이에 감사드 립니다.

\section{References}

1. Kim GY, Kim SH, Kim WS, Kim CH, Nam MS, Moon YI, Bae IH, Oh SJ, Yoon SS, Lee SW, Lee WJ, Jun WM, Ha WG (2011) Milk processing technology. Yu Han Publishing Co., Seoul, Korea, p 287

2. Kim HU (1999) Milk processing technology : based process - manufacture of milk product. Sun Jin Publishing Co., Seoul, Korea, p 517

3. Ronsivalli LJ, Vieira ER (1990) Elementary food science 3rd edition. Van Nostrand Reinhold Co., NY, USA, p 226

4. Kosikowski FV (1979) Whey utilization and whey products. J Dairy Sci, 62, 1149-1155

5. Park HM, Hong YH, Oh SH (1988) Studies on the development of whey drinks. Korean J Dairy Sci, 10, 92-100

6. Nam MS (2013) Health benefits and industrial availability of whey. Korean J Food Sci Ani Resour, 2, 2

7. Kosikowski FV (1982) Cheese and fermented milk foods 2nd ed. Edwards Bros Inc., Ann Arbor, MI, USA

8. Kim SH (2011) Studies on production of health beverage using whey protein and whey. MS Thesis. Konkuk University, Seoul, Korea, p 1

9. Zafar S, Owais M (2006) Ethanol production from crude whey by Kluyveromyces marxianus. Biochem Eng J, 27, 295-298

10. Dragone G, Mussatto SI, Oliveira JM, Teixeira JA (2009) Characterisation of volatile compounds in an alcoholic beverage produced by whey fermentation. J Food Chem, 112, 929-935

11. Gawel J, Kosikowski FV (1978) Improving alcohol fermentation in concentrated ultra filtration permeates of cottage cheese whey. J Dairy Sci, 43, 1717-1719

12. Kosikowski FV, Wzorek W (1977) Whey wine from concentrates of reconstituted acid whey powder. J Dairy Sci, 60, 1982-1986

13. Shim YS, Kim JW, Yoon SS (1998) Alcohol fermentation of cheese whey by Kluyveromyces marxianus and lactic acid bacteria. Korean J Food Sci Technol, 30, 161-167
14. Kim SP, Paek HK, Kim DH, Heo TR (1995) Utilization of cheese whey for alcohol fermentation medium. Korean J Food Sci Technol, 27, 878-884

15. Yang JY, Lee KH (1996) Shelf-life and microbiological study of Sansung Takju. Korean J Food Sci Technol, 28, 779-785

16. Lee YJ, Yi HC, Hwang KT, Kim DH, Kim HJ, Jung CM, Choi YH (2012) The qualities of Makgeolli (Korean rice wine) made with different rice cultivars, milling degrees of rice and Nuruks. Korean J Soc Food Sci Nutr, 41, 1785-1791

17. Park CW (2012) Quality characterization of rice Makgeolli prepared by using different ferment mixtures and yeasts strains. MS Thesis. Kyungpook National University, Daegu, Korea

18. Lee HN (2013) Quality characteristics of Makgeolli added with cranberry. MS Thesis. Myongji University, Seoul, Korea

19. Kim EK, Chang YH, Ko JY, Jeong YH (2013) Quality characteristics of Makgeolli added with kiwifruit (Actinidia deliciosa). J Korean Soc Food Sci Nutr, 42, 1821-1828

20. Lee HW (2008) Studies on Takju brewing with birch sap. MS Thesis. Seoul National University of Technology, Seoul, Korea

21. Son HS, Park BD, Ko BK, Lee CH (2011) Quality characteristics of Takju produced by adding different amounts of water. Korean J Food Sci Technol, 43, 4, 453-457

22. Wilson AM, Work TM, Bushway AA, Bushway RJ (1981) HPLC determination of fructose, glucose and sucrose in potatoes. J Food Sci, 46, 300

23. Jung DH, Jang HG (1982) Newest food analysis. Samjungdang Publishing Co., Seoul, Korea

24. Vidal-Valverde C, Prodanov M, Sierra I (1997) Natural fermentation of lentils : influence of time, temperature and flour concentration on the kinetics of thiamine, riboflavin and niacin. Eur Food Res Technol, 205, 464-469

25. Duncan DB (1955) Multiple range and multiple F test. Biometrics, 11, 1-42

26. Charis M, Galanakis, Stathis Chasiotis, George Botsaris, Vassilis Gekas (2014) Separation and recovery of proteins and sugars from halloumi cheese whey. Food Res Int, $65,477-483$

27. NAQS (2013) Criteria of alcohol quality certification. National agricultural products quality management 
Service Announcement, No. 2013-12

28. Kwon SJ (2010) Analysis of microbial diversity in Makgeolli fermentation. MS Thesis. Dankook University, Yongin, Korea

29. Kim SY, Kim EK, Yoon SJ, Namji Jo, Jung SK, Kwon SH, Chang YH, Jeong YH (2011) Physicochemical and microbial properties of Korean traditional rice wine, Makgeolli, supplemented with cucumber during fermentation. J Korean Soc Food Sci Nutr, 40, 223-228

30. Park CW, Jang SY, Park EJ, Yeo SH, Jeong YJ (2012)
Quality characteristics of rice Makgeolli prepared by mashing types. Korean J Food Sci Technol, 44, 2, 207-215

31. Lee JS, Lee TS, Noh BS, Park SO (1996) Quality characteristics of mash of Takju prepared by different raw materials. Korean J food Sci Technol, 28, 330-336

32. Lee SJ, Kim JH, Jung YW, Park SY, Shin WC, Park CS, Hong SY, Kim GW (2011) Composition of organic acids and physiological functionality of commercial Makgeolli. Korean J Food Sci Technol, 43, 206-212 